\title{
Niche partitioning among three tree-climbing bird species in subtropical mountain forest sites with different human disturbance
}

\author{
Carlos Lara ${ }^{1 *}$, Berenice Pérez ${ }^{1}$ Citlalli Castillo-Guevara ${ }^{1}$ and Martín Alejandro Serrano-Meneses ${ }^{2}$
}

\begin{abstract}
Background: Closely related and ecologically similar species that overlap in ranges can coexist through resource partitioning without one pushing the others to extinction through competition. Understanding resource partitioning among species is essential to predicting how species decline can affect the functioning of communities and ecosystems. In this study, we analyzed niche overlap and resource partitioning of three tree-climbing bird species in disturbed and undisturbed forest sites at La Malinche National Park, Tlaxcala, Mexico. From January to December 2008, resource partitioning between the three species was examined through the frequency of sightings of individuals foraging in different sites in the trees of both forest types. We characterized the pattern of resource utilization by niche breadth and niche overlap. Finally, we tested if these birds divide tree space differentially according to forest type.

Results: Our results indicate that in undisturbed sites, pygmy nuthatches had a high niche breadth (foraging significantly more on the thin branches), while white-breasted nuthatches and brown creepers had similar medium niche breadth values (more often foraged in thick branches and lower trunk, respectively), causing the last two to have a high niche overlap. In contrast, in disturbed sites, niche breadth and overlap values were similar for all three tree-climbing species. All observed overlaps for both forest types were higher than expected, but expected values in disturbed sites suggest the possibility of competition on these sites. Pygmy nuthatches were more sighted than white-breasted nuthatches and brown creepers in both forest types.

Conclusions: Our study shows that differences in tree use suggest resource partitioning among the three bird species, particularly at undisturbed sites. However, activities of excessive logging and grazing in the disturbed sites resulted in niche overlap among species. This could lead to changes in competitive dynamics among them.
\end{abstract}

Keywords: Brown creeper; Pygmy nuthatch; White-breasted nuthatch; Niche overlap; Null models; Resource partitioning

\section{Background}

Numerous studies of avian communities have elucidated differences between similar species inhabiting the same habitat which lead to coexistence (MacArthur 1958, Hutchinson 1961, Alatalo and Alatalo 1979, Leyequién et al. 2007, Lara et al. 2011, Cloyed 2014). The general view, in the face of interspecific competition, is that the primary way to achieve this coexistence is for species to show a differential use of resources (Hutchinson 1961, Schoener 1974, Pyke 1982, Young et al. 2010). However,

\footnotetext{
* Correspondence: laracar@posgradouatx.com.mx

'Centro de Investigación en Ciencias Biológicas, Universidad Autónoma de Tlaxcala, Km. 10.5 Autopista Tlaxcala-San Martín Texmelucan, San Felipe Ixtacuixtla, Tlaxcala 90120, Mexico

Full list of author information is available at the end of the article
}

the fact that many sympatric species do not appear to differ sufficiently in their morphology to allow for niche differentiation (Wellborn and Cothran 2007) has challenged this view.

Nuthatches, woodpeckers, and brown creepers are all considered to be tree-climbing birds. They have claws that allow them to grip onto bark for insect capture. From these bird species, the Sittidae (the nuthatchers and wallcreepers Sitta and Thrichoma) are the sister group to the Certhiidae (the creepers, Certhia and Salpornis) (Sibley and Ahlquist 1990). Certhia americana and bird species from the Sitta genus are common inhabitants of North American temperate forest. These tree climbers show morphological similarities in their beaks (slender, either straight or decurved) and body size 
(ranging from 11 to $15 \mathrm{~cm}$ of total length). Despite this, they may show pronounced spatial segregation of primary foraging microhabitats in a tree. For example, previous studies have shown that pygmy nuthatches (Sitta pygmaea) forage higher up in the tree and use their branches more frequently than the trunk (Stallcup 1968, McEllin 1979). Conversely, white-breasted nuthatches (Sitta carolinensis) forage more often on the trunks (Stallcup 1968, McEllin 1979), as do brown creepers (C. americana) (Willson 1970). In this context, differences in the use of hunting tactics or substrates to find prey items should facilitate niche differentiation in sympatric tree-climbing birds (Cloyed 2014).

Forest structure has been highlighted as important for birds that feed on trees (Robinson and Holmes 1982, Whelan 2001). Constraints imposed by the structure of the vegetation and by the types and abundances of prey determine the available foraging opportunities. Such habitat parameters may affect foraging behavior to exploit a particular habitat and hence influence the patterns of bird habitat selection and ultimately the community structure (Robinson and Holmes 1982). Habitat disturbances such as grazing or fire may affect size class distribution of trees (Wimberly and Spies 2001). Thus, changes in habitat structure from habitat disturbance may affect tree use for climbing birds by altering their distribution. If this occurs, then the resource partitioning among these bird species could be affected.

Integrating these observations led us to hypothesize that due to their morphological similarities and sympatry, (1) the three tree-climbing bird species above mentioned should show a differential tree use to coexist, (2) but if the forest structure is altered, such resource partitioning can be modified. In this study, we analyzed niche overlap and resource partitioning of sympatric pygmy nuthatches, white-breasted nuthatches, and brown creepers in disturbed and undisturbed forest sites at La Malinche National Park, Tlaxcala, Mexico. We examined the frequency of sightings of individuals foraging in different sites in the trees of both forest types over an annual period. Then, we characterized the pattern of resource utilization by niche breadth and niche overlap. Finally, we tested if these birds divide tree space differentially according to forest type.

\section{Methods}

\section{Study site}

Niche partitioning among the three tree-climbing bird species was assessed from January through December 2008 in a representative area of vegetation $(250 \mathrm{ha})$ at the La Malinche National Park (MNP), Tlaxcala, Mexico. About half of this area comprises undisturbed forests with ongoing management to prevent fires. The rest comprises disturbed forests that have suffered constant grazing, illegal logging, and numerous fire events during the last 20 years. The MNP forms part of the Trans-Mexican Volcanic Belt. It has an area of 46,093 ha, located between the $19^{\circ} 14^{\prime} \mathrm{N}$ and $98^{\circ} 14^{\prime} \mathrm{W}$, with an altitude ranging from 2,300 to 4,461 $\mathrm{m}$ a.s.l. (LópezDomínguez and Acosta 2005). Mean annual precipitation is $800 \mathrm{~mm}$, the rainy season is between June and October, and mean annual temperature is $15^{\circ} \mathrm{C}$. Coniferous forest is the dominant kind of vegetation. Below 3,000 m, we find primary pine forest dominated by Pinus montezumae Lamb., Pinus teocote Schl. \& Chamb., and Pinus leiophylla Schl. \& Chamb. The dominant species in the herbaceous stratum are Lupinus aschenbornii Schauer., Castilleja tenuiflora Benth., Penstemon roseus, Senecio salignus DC, and Prunella vulgaris L. Above $3,000 \mathrm{~m}$, the forest is dominated by old-growth fir forest (Abies religiosa HBK.), frequently mixed with Pinus hartwegii Lindl. In the lower stratum are found some shrubs and trees such as Salix mexicana Seemen and Buddleja parviflora HBK. Above 3,500 m, Pinus forest contains pure stands of $P$. hartwegii and $A$. religiosa. The main shrubs are Baccharis conferta HBK and Eupatorium glabatrum HBK. Plants of the herbaceous layer include Senecio platanifolius Benth., Muhlenbergia macroura HBK., and Penstemon gentianoides HBK. (Villers et al. 2006).

We divided the study area into two forest types according to the conservation status of vegetation (undisturbed and disturbed). The undisturbed forest consisting of dense stands of fir and pine trees was $80 \%$ to $90 \%$ tree-covered, with tree heights ranging from 20 to $35 \mathrm{~m}$ and diameters at breast height (DBHs) of 2 to $5 \mathrm{~m}$. The disturbed forests were more open (crown cover of less than $40 \%$ ) and were represented by a mosaic of burned fir and pine forest (with annual fire events), pasture, and second-growth vegetation from burning of the original forest or in abandoned agricultural areas. Most of the trees in these areas are less than $20 \mathrm{~m}$ in height, and DBHs are smaller than $1 \mathrm{~m}$ (C Lara, personal observations). Both forest types are located in a range of 2,900 to 3,100 m.a.s.l and approximately $2 \mathrm{~km}$ apart.

\section{Tree-climbing bird monitoring}

Prior to bird monitoring and in order to determine differences between the climbing bird species in the foraging sites in a tree, we divided the fir and pine trees into three foraging sites: lower trunk (trunk below any branches), thick branches (branches with a diameter larger than $15 \mathrm{~cm}$ and located inside the tree crown), and thin branches (branches with a diameter smaller than 15 $\mathrm{cm}$ and located on the periphery of the tree crown). We measured the frequency of each foraging site for each bird species in both forest types. Four 800-m transects that were $500 \mathrm{~m}$ apart were established in the study area (two transects per forest type) with no previous 
knowledge of bird distribution. We performed the point count at an interval of $200 \mathrm{~m}$ along each transect in each forest type. The censuses began at 0730 hours, and we counted individuals at each point within a radius of $50 \mathrm{~m}$. Binoculars $(10 \times 50 \mathrm{~mm})$ were used, and species were identified using field guides (Sibley 2003, van Perlo 2006). The observers recorded data at each point count for $10 \mathrm{~min}$ and recorded sighted individuals by species and feeding site (according to categories described above). The spacing of each point count location was sufficient to ensure that one bird was not counted twice or more during a single transect survey. Thus, we used the number of sightings as proxy to bird abundance. We performed observations on each transect every 2 weeks and each transect was done a total of 24 times. The data for all four transects were compiled into a frequency matrix of tree-climbing birds sighted per counting event.

In order to identify niche partitioning among the three tree-climbing species, we first calculated the proportion of sightings in each foraging site for each bird species and forest type. According to De Cáceres et al. (2011), the notation for Rao's quadratic entropy (Rao 1982) was adopted for niche breadth: $B_{D}=1 / 2 \Sigma_{j=1}^{\mathbf{2 4}} \Sigma^{\mathbf{2 4}}{ }_{k=1} f_{\mathrm{j}} f_{\mathrm{k}} d^{2}{ }^{2 \mathrm{k}}$, where $f$ is the relative abundance of foraging sites for each counting event and $d_{\mathrm{jk}}$ is the distance between counting events $j$ and $k$. The distance was given by difference of the foraging site values between the two counting events. The minimum niche breadth is 0 ; this value is obtained when all resources used are equal or when a single resource is used.

Niche overlaps were calculated between all pairs of species with the index of Pianka (1973): $O_{\mathrm{jk}}=\left(\Sigma p_{\mathrm{ij}} p_{\mathrm{ik}}\right)$ $\left(\Sigma p_{\mathrm{ij}}{ }^{2}{p_{\mathrm{ik}}}^{2}\right)-1 / 2$, where $p_{\mathrm{ij}}$ and $p_{\mathrm{ik}}$ are proportional values of utilization of resource $i$ by species $j$ and $k$, respectively. Pianka's index is symmetrical and assumes values ranging from 0 (no resources used in common between two species) to 1 (complete overlap in resource use).

\section{Data analysis}

Niche breadth was estimated using $R$ and the 'resniche' package (R Development Core Team 2012). Rao's quadratic entropy (Rao 1982) is a general diversity measure that has been recently recommended to assess both functional and taxonomic diversity and whose mathematical properties have been extensively studied (De Cáceres et al. 2011). This index incorporates the resemblance between resources into the calculation of resource niche metrics. This not only allows estimation of the niche breadth with greater accuracy but also makes the estimates less influenced by the way the resources are subdivided. In addition, all niche metrics can be calculated while taking into account the variation in resource availability, and confidence intervals can be obtained by bootstrapping (De Cáceres et al. 2011).
Similarity in foraging site used among the three bird species in both forest types was calculated as Bray-Curtis similarity coefficient in cluster analyses. EcoSim (Acquired Intelligence, Inc., Victoria, BC, Canada) was then used to estimate niche overlap with Pianka (1973) overlap index using Lawlor's (1980) third randomization algorithm (RA3). The RA3 has been shown to have desirable statistical properties for detecting nonrandom niche overlap patterns (Winemiller and Pianka 1990). EcoSim not only generates a niche overlap value from the observed data but also produces a statistical value based on a null distribution of randomized raw data to test the significance of the overlap value. The RA3 retains values for niche breadth but randomly reshuffles these values including any zeros among foraging site categories for each bird species. This permutation step was repeated for a total of 5,000 Monte Carlo simulations (Gotelli et al. 2004). The overlap indices from each permutation were used to generate a distribution of overlap values based on randomized data matrices that retained qualitative characteristics of the original data. We then used this null distribution of the overlap index values to test for statistical significance of the observed overlap index value. Significance levels were based on $99 \%$ confidence intervals.

To test for differences in foraging site used among the three bird species (number of sightings as response variable) in both forest types, we used a generalized linear mixed effects model (GLMM) where bird species, foraging area, and forest type were the fixed factors and month (point count event) was a random effect. Data were log transformed, and we used a Poisson distribution with log link function in the GLMM. All statistical tests were done in R (R Development Core Team 2012).

\section{Results}

\section{Niche measurements}

The three tree-climbing species were recorded foraging in different sites in the trees in both forest types throughout the study. In the undisturbed site, niche breadth of both white-breasted nuthatches and brown creepers was smaller than the niche breadth of pygmy nuthatches. However, in the disturbed site, niche breadth values were similar for the three tree-climbing species (Table 1).

Bray-Curtis coefficients of similarity in the foraging site used by the three bird species in both forest types divided the species into two major groups (Figure 1). The first group represented foraging sites where birds were sighted in the undisturbed forest. Here, whitebreasted nuthatches and brown creepers had a mutual Bray-Curtis similarity in their foraging sites of about $70 \%$. However, pygmy nuthatches were sighted in foraging sites less similar $(\approx 30 \%)$ in relation to the other bird species. The other group represented birds from the disturbed forest. The three bird species had a mutual 
Table 1 Niche breadth values (Rao's quadratic entropy) and $95 \%$ confidence intervals

\begin{tabular}{lllll}
\hline Species & $\boldsymbol{n}$ & Niche breadth & LCI & UCI \\
\hline (a) & 17 & 0.13 & 0.11 & 0.17 \\
$\quad$ Brown creeper & 34 & 0.28 & 0.19 & 0.35 \\
$\quad$ Pygmy nuthatch & 19 & 0.14 & 0.09 & 0.18 \\
$\quad$ White-breasted nuthatch & & & & \\
(b) & 24 & 0.11 & 0.08 & 0.17 \\
Brown creeper & 50 & 0.12 & 0.09 & 0.19 \\
Pygmy nuthatch & 29 & 0.11 & 0.08 & 0.16 \\
White-breasted nuthatch & 29 &
\end{tabular}

Niche breadth values and 95\% confidence intervals for brown creepers (Certhia americana), pygmy (Sitta pygmaea), and white-breasted nuthatches ( $S$. carolinensis) based on sightings and foraging use of trees in (a) disturbed and (b) undisturbed forest sites.

similarity of about $65 \%$ to $60 \%$, showing that they were almost always sighted using the same foraging sites in this forest type.

Although the occurrence of some of the three bird species appears to be similar in both forest types, the foraging sites where they were more frequently sighted indicate a differential use of resources, which directly affects the overlap of their niches. Pianka's index of niche overlap was calculated using the frequency of birds sighted in each foraging site within a tree (Table 2). In the undisturbed forest, the higher overlap occurred between white-breasted nuthatches and brown creepers, and overlap was lowest between the nuthatch species.

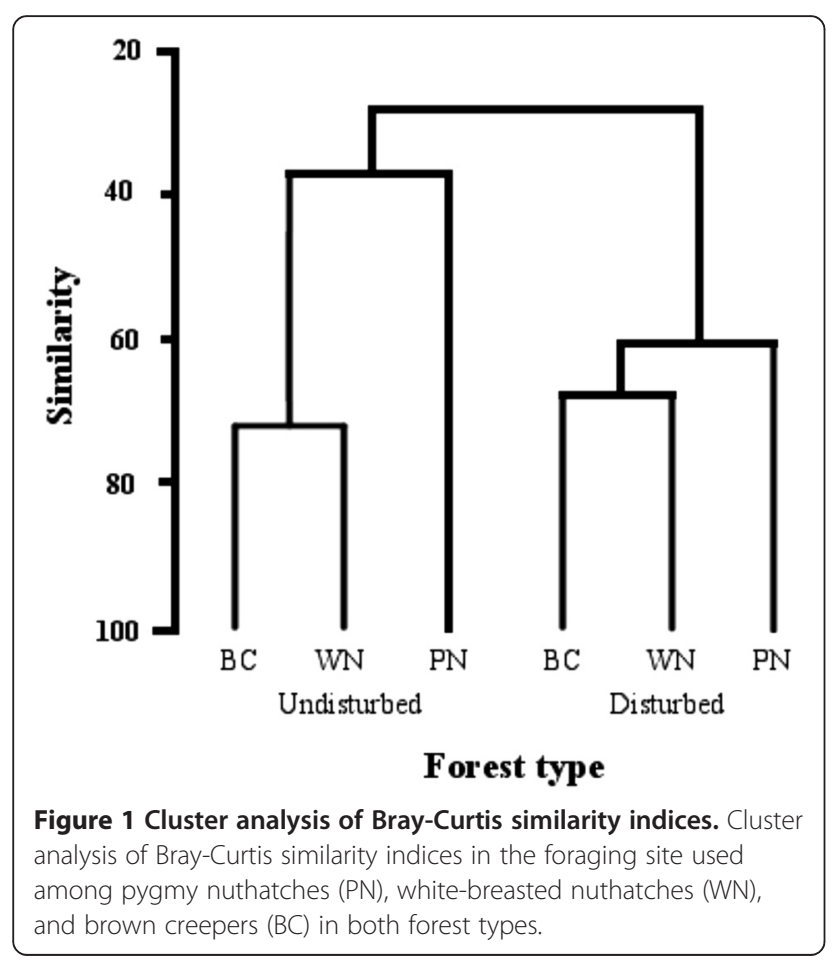

Table 2 Niche overlap for tree use among the three species studied

\begin{tabular}{llll}
\hline Species & $\begin{array}{l}\text { Brown } \\
\text { creeper }\end{array}$ & $\begin{array}{l}\text { Pygmy } \\
\text { nuthatch }\end{array}$ & $\begin{array}{l}\text { White-breasted } \\
\text { nuthatch }\end{array}$ \\
\hline (a) & 1 & 0.523 & 0.691 \\
$\quad$ Brown creeper & 1 & 1 & 0.477 \\
$\quad$ Pygmy nuthatch & 0.523 & 1 \\
$\quad$ White-breasted nuthatch & 0.691 & 0.477 & 1 \\
(b) & & & \\
$\quad$ Brown creeper & 1 & 0.413 & 0.769 \\
$\quad$ Pygmy nuthatch & 0.413 & 1 & 0.277 \\
$\quad$ White-breasted nuthatch & 0.769 & 0.277 & 1 \\
\hline
\end{tabular}

Niche overlap for tree use among brown creepers (Certhia americana), pygmy (Sitta pygmaea), and white-breasted nuthatches (S. carolinensis) in (a) disturbed and (b) undisturbed forest, determined by Pianka's index. After 5,000 Monte Carlo simulations, the observed mean tree use overlap in the disturbed forest $(0.753)$ differed from the expected mean $(0.614)$ for tree use overlap $(p<0.01)$. In the undisturbed forest, the observed mean tree use overlap (0.682) differed from the expected mean $(0.192)$ tree use overlap $(p<0.01)$.

However, in the disturbed forest, overlap values were similar among the three bird species. All observed overlaps for both forest types were higher than expected (Table 2).

\section{Habitat and tree use}

Pygmy nuthatches were more sighted than whitebreasted nuthatches and brown creepers throughout the study. The lower number of sightings was recorded in the thick branches. Overall, the undisturbed forest had the most bird sightings (Table 3). Compared to brown creepers and white-breasted nuthatches, pygmy nuthatches foraged significantly more on the thin branches. Conversely, brown creepers more often foraged in the thick branches, and white-breasted nuthatches foraged significantly more on the lower trunk. White-breasted nuthatches and brown creepers were less sighted in disturbed forest sites (Figure 2, Table 3).

\section{Discussion}

As predicted, the three sympatric tree-climbing bird species partitioned their resources by foraging in different

Table 3 Results of GLMM

\begin{tabular}{llll}
\hline Source & $\boldsymbol{F}$ & $\boldsymbol{d f}$ & $\boldsymbol{p}$ \\
\hline Species & 15.16 & 2 & $<0.001$ \\
Foraging site & 17.22 & 2 & $<0.001$ \\
Forest type & 13.28 & 1 & $<0.001$ \\
Species $\times$ foraging site & 9.31 & 4 & $<0.001$ \\
Species $\times$ forest type & 1.16 & 2 & 0.007 \\
Foraging site $\times$ forest type & 0.27 & 2 & 0.707 \\
Species $\times$ foraging site $\times$ forest type & 1.18 & 4 & 0.014 \\
\hline
\end{tabular}

Results of GLMM testing the influence of bird species, foraging site used, forest type, and their interactions on the number of sightings (in this analysis, 'month' was included as a random effect). 


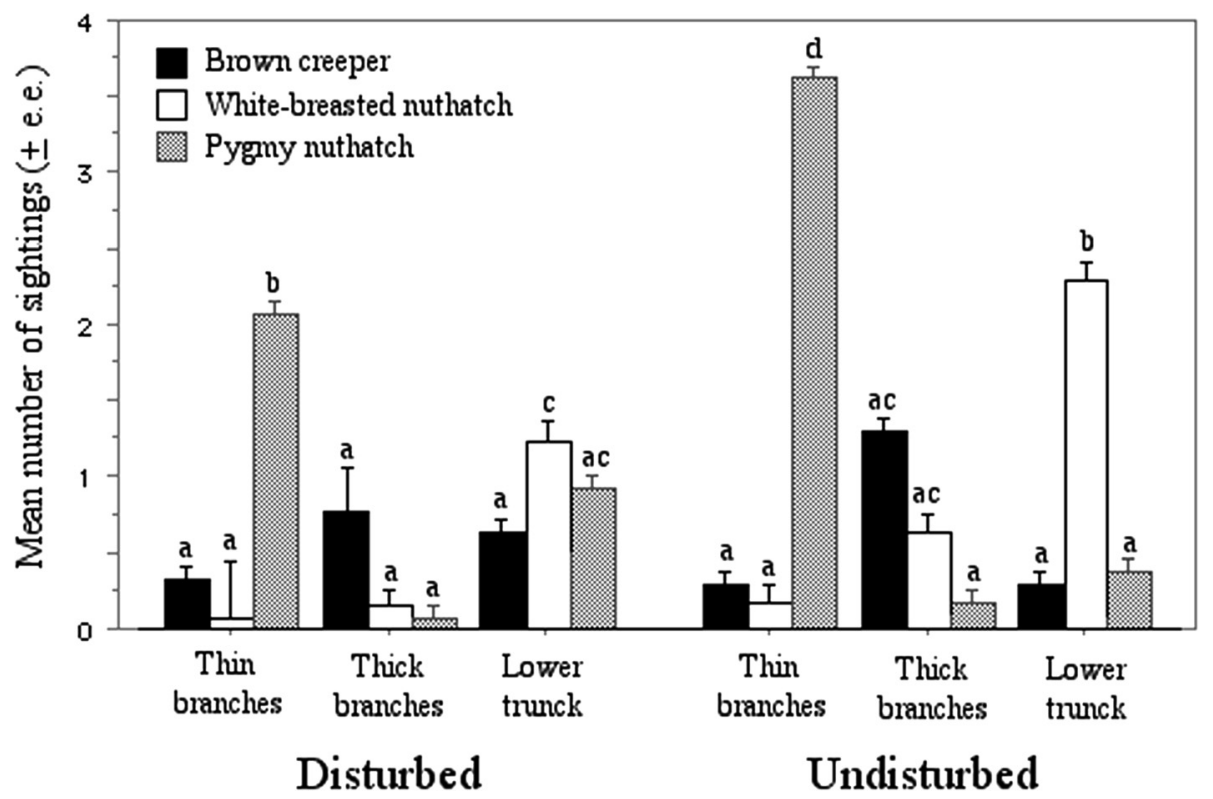

Figure 2 Mean number of sightings in the foraging site used among the three bird species in both forest types. Data with the same superscript letters are not significantly different between groups $(p<0.05)$.

parts of a tree. We found that in the undisturbed sites, pygmy nuthatches were more frequently seen foraging on the thin branches, while white-breasted nuthatches and brown creepers were seen foraging mostly in the thick branches and lower trunk, respectively. Conversely, in the disturbed sites, the three bird species were more homogeneous with respect to the site of the tree in which they foraged. This pattern caused their niche breadth and overlap values to be similar.

The differential use of substrates to find prey items is a widespread way in which ecologically similar and closely related forest-dwelling birds partition their resources (MacArthur 1958, Holmes et al. 1979, Morrison and With 1987). This niche differentiation model assumes that resource partitioning results from different fundamental niches having been occupied through past competition (Keddy 1989). Different tree use and the associated morphological attributes that make foraging in those places more efficient may represent a mechanism that minimizes interspecific competition (called the ghost of competition past, Connell 1980). Thus, resource partitioning between nuthatches and the brown creeper can be explained by the niche differentiation model. Previous studies had shown that in communities where different nuthatch species (e.g., S. carolinensis, S. canadensis, $S$. pygmaea) are sympatric with brown creepers (e.g., $C$. americana, C. familiaris), niche differentiation occurs, particularly through dividing trees spatially and by using different hunting tactics (Willson 1970, Williams and Batzli 1979, Morrison et al. 1987). This pattern has even been detected within nuthatch species. For example, in
North American ponderosa pine forests, sympatric pygmy and white-breasted nuthatches partition their resources by foraging in different parts of the tree (Stallcup 1968, McEllin 1979, Cloyed 2014). Our results confirm these findings. Although prey distribution can affect habitat use among sympatric climbing bird species, additional research is needed to determine the importance of abiotic factors (e.g., light and temperature) in different seasons.

The data obtained in our undisturbed pine forest sites at La Malinche provided support to previous results of resource partitioning among tree-climbing birds. It is possible that in these forested sites, abundance asymmetry and niche breadth could potentially be acting as mechanisms for coexistence. However, changes in tree use by the studied bird species in disturbed forest sites have not been previously reported. In the only study done in this area, Cloyed (2014) examined how pygmy and white-breasted nuthatches divided their resources in two ponderosa pine forest sites, an untreated forest (mostly comprised of trees with trunks higher than 32-cm DBH), and a forest selectively thinned for small-diameter trees (less than $32 \mathrm{~cm}$ ). He found that the areas used in the trees by the two bird species are different when foraging on large- or small-diameter trees, but partition in tree use remains in both forest conditions. From this data, the author concluded that pygmy nuthatches have a foraging niche in thinned and unthinned forests that is distinct from white-breasted nuthatches, allowing them to coexist without potential population implications. Our data, consistent with the differential tree use in nuthatches reported by Cloyed (2014) and the estimated niche 
overlaps (including brown creepers), suggest that changes in forest structure could lead to changes in competitive dynamics among them, as discussed below.

Preferences for larger-diameter (white-breasted nuthatches), medium-diameter (brown creepers), and smalldiameter (pygmy nuthatches) tree sections have been tested in both laboratory (Pierce and Grubb 1981, Cloyed 2014) and natural conditions (Willson 1970, Williams and Batzli 1979, Morrison et al. 1987). Moreover, these preferences denote characteristics that trees should have to search for food and a change in the species or size composition of the forest that would likely alter the pattern of resource used by these bird species. For example, Morrison et al. (1987) showed that foraging behaviors used by bark foragers in the Sierra Nevada, California, were consistent with tree composition due to silvicultural management. These observations gave credence to our hypothesis that a change in forest structure must involve a change in the resource partition between sympatric species such as those studied here. Compared to undisturbed sites, the disturbed forest sites we studied showed a direct effect on the tree-climbing birds. For example, the three bird species were less abundant in these sites throughout the study, their niche breadth indices were lower, and conversely the overlap was larger among them. Thus, our results suggest that activities of excessive logging and grazing in the disturbed sites at La Malinche can affect size class distribution of trees (Peterson and Reich 2001) and that tree-climbing birds are responding to this. A possible effect of abundance and frequency of availabilities of foraging sites (lower trunk, thin branches, and thick branches) in our study site requires further investigation. Results from the null models showed that the observed overlaps were higher than expected, particularly in undisturbed forest sites. However, the expected values estimated for the disturbed sites were already high, suggesting that species have to share the habitat to a higher degree even when they distributed themselves randomly in the tree, making it difficult for them to reduce competition through niche partitioning (Gotelli and Graves 1996). This adds to the growing number of studies that demonstrate negative effects of changes in forest structure promoted by human activities for some bird species at the behavioral and population levels (Desrochers and Fortin 2000, Blake 2005, Whelan and Maina 2005, Barbaro et al. 2012).

\section{Conclusions}

In short, our study showed that tree-climbing bird species perform a differential use of space in the trees to forage, which promotes their coexistence particularly at undisturbed sites. However, activities of excessive logging and grazing in the disturbed sites resulted in niche overlap among species, and this could lead to changes in competitive dynamics among them. Future studies analyzing the mechanisms that structure tree-climbing bird communities should include the potential impact of foresting practices.

\section{Competing interests}

The authors declare that they have no competing interests.

\section{Authors' contributions}

$\mathrm{CL}$ conceived the study, participated in its design and coordination, performed the statistical analysis, and drafted the manuscript. BP carried out the fieldwork and participated in its design. CCG participated in the design of the study. MASM participated in the design. All authors read and approved the final manuscript.

\section{Acknowledgements}

We thank Hellen Martínez Roldán and Jheny González Méndez for their help during fieldwork. Two anonymous reviewers provided enriching comments and thorough grammar revision on a previous version. We also thank the staff of the Caseta No. 5 of the Coordinación General de Ecología del Estado de Tlaxcala for access to their facilities. This work was supported by CACyPI-UATx-2014.

\section{Author details}

${ }^{1}$ Centro de Investigación en Ciencias Biológicas, Universidad Autónoma de Tlaxcala, Km. 10.5 Autopista Tlaxcala-San Martín Texmelucan, San Felipe Ixtacuixtla, Tlaxcala 90120, Mexico. 'Laboratorio de Biología Evolutiva, Centro Tlaxcala de Biología de la Conducta, Universidad Autónoma de Tlaxcala, Carretera Tlaxcala-Puebla, Km. 1.5, 90062 Tlaxcala, Mexico.

Received: 4 September 2014 Accepted: 19 January 2015

Published online: 16 February 2015

\section{References}

Alatalo RV, Alatalo RH (1979) Resource partitioning among a flycatcher guild in Finland. Oikos 33:46-54

Barbaro L, Brockerhoff EG, Giffard B, van Halder I (2012) Edge and area effects on avian assemblages and insectivory in fragmented native forests. Landsc Ecol 27:1451-63

Blake JG (2005) Effects of prescribed burning on distribution and abundance of birds in a closed-canopy oak-dominated forest, Missouri, USA. Biol Conserv 121:519-31

Cloyed CS (2014) Forest structure affects resource partitioning between pygmy and white-breasted nuthatches. Coevolution 2:26-30

Connell JH (1980) Diversity and the coevolution of competitors, or the ghost of competition past. Oikos 35:131-8

De Cáceres M, Sol D, Lapiedra O, Legendre PA (2011) Framework for estimating niche metrics using the resemblance between qualitative resources. Oikos 120:1341-50

Desrochers A, Fortin MJ (2000) Understanding avian responses to forest boundaries: a case study with chickadee winter flocks. Oikos 91:376-84

Gotelli NJ, Graves GR (1996) Null models in ecology. Press, Smithsonian Institution

Gotelli NJ, GL Entsminger. EcoSim: null models software for ecology. Version 7. Acquired Intelligence Inc. \& Kesey-Bear. Jericho, VT 05465. Computer software. http://garyentsminger.com/ecosim/index.htm. (accessed on 19-04-2014); 2004.

Holmes RT, Bonney RE Jr, Pacala SW (1979) Guild structure of the Hubbard Brook bird community: a multivariate approach. Ecology 60:512-20

Hutchinson GE (1961) The paradox of the plankton. Am Nat 95:137-45 Keddy PA (1989) Competition. Chapman and Hall, London

Lara C, Martinez-Garcia V, Ortiz-Pulido R, Bravo-Cadena J, Loranca S, Cordoba-Aguilar A (2011) Temporal-spatial segregation among hummingbirds foraging on honeydew in a temperate forest in Mexico. Current Zoology 57:56-62 Lawlor LR (1980) Overlap, similarity, and competition coefficients. Ecology 61:245-51

Leyequién E, de Boer WF, Cleef A (2007) Influence of body size on coexistence of bird species. Ecol Res 22:735-41

López-Domínguez JC, Acosta R (2005) Descripción del Parque Nacional La Malinche. In: Fernández-Fernández JA, López-Domínguez JC (eds) Biodiversidad del Parque Nacional La Malinche. Coordinación General de 
Ecología del Gobierno del Estado de Tlaxcala, Tlaxcala, Tlaxcala, México, pp 20-30

MacArthur RH (1958) Population ecology of some warblers of northeastern coniferous forests. Ecology 39:599-619

McEllin SM (1979) The role of insectivorous birds in forest ecosystems. In: Dickson JG, Conner RN, Fleet RR, Kroll JC, Jackson JA (eds) Population demographies, spacing, and foraging behaviors of white-breasted and pygmy nuthatches in ponderosa pine habitat. Academic Press, NY, pp 301-29

Morrison ML, With KA (1987) Interseasonal and intersexual resource partitioning in hairy and white-headed woodpeckers. Auk 104:225-33

Morrison ML, With KA, Timossi IC, Block WM, Milne KA (1987) Foraging behavior of bark-foraging birds in the Sierra Nevada. Condor 89:201-4

Peterson DW, Reich PB (2001) Prescribed fire in oak savanna: fire frequency effects on stand structure and dynamics. Ecol Appl 11:914-27

Pianka ER (1973) The structure of lizard communities. Ann Rev Ecol Syst 4:53-74

Pierce V, Grubb TC Jr (1981) Laboratory studies of foraging in four bird species of deciduous woodland. Auk 98:307-20

Pyke GH (1982) Local geographic distributions of bumblebees near Crested Butte, Colorado: competition and community structure. Ecology 63:555-73

R Development Core Team (2012) R: a language and environment for statistical computing. R Foundation for Statistical Computing, ISBN 3-900051-07-0, Vienna, Austria, Available at http://www.r-project.org/. Accessed 22 october 2012

Rao CR (1982) Diversity and dissimilarity coefficients: a unified approach. Theor Popul Biol 21:24-43

Robinson SK, Holmes RT (1982) Foraging behavior of forest birds: the relationships among search tactics, diet, and habitat structure. Ecology 63:1918-31

Schoener TW (1974) Resource partitioning in ecological communities. Science 185:27-39

Sibley D (2003) Sibley field guide to birds of eastern North America. Knopf Doubleday Publishing Group

Sibley CG, Ahlquist JE (1990) Phylogeny and classification of birds: a study in molecular evolution. Yale University Press, New Haven, Conn. Publishing Group

Stallcup PL (1968) Spatio-temporal relationships of nuthatches and woodpeckers in ponderosa pine forests of Colorado. Ecology 49:831-43

van Perlo B (2006) Birds of Mexico and Central America. Princeton University Press, Princeton

Villers RL, Rojas GF (2006) LP Tenorio. Guía Botánica del Parque Nacional Malinche Tlaxcala - Puebla. Univ. Nacional Autónoma de México, México. D. F., México

Wellborn GA, Cothran RD (2007) Niche diversity in crustacean cryptic species: complementarity in spatial distribution and predation risk. Oecologia 154:175-83

Whelan CJ (2001) Foliage structure influences foraging of insectivorous forest birds: an experimental study. Ecology 82:219-31

Whelan CJ, Maina GG (2005) Effects of season, understorey vegetation density, habitat edge and tree diameter on patch-use by bark-foraging birds. Funct Ecol 19:529-36

Williams JB, Batzli GO (1979) Competition among bark-foraging birds in central Illinois: experimental evidence. Condor 81:122-32

Willson MF (1970) Foraging behavior of some winter birds of deciduous woods. Condor 72:169-74

Wimberly MC, Spies TA (2001) Influences of environment and disturbance on forest patterns in coastal Oregon watersheds. Ecology 82:1443-59

Winemiller KO, Pianka ER (1990) Organization in natural assemblages of desert lizards and tropical fishes. Ecol Monogr 60:27-55

Young HS, Shaffer SA, McCauley DJ, Foley DG, Dirzo R, Block BA (2010) Resource partitioning by species but not sex in sympatric boobies in the central Pacific Ocean. Mar Ecol Prog Ser 403:291-301

Submit your manuscript to a SpringerOpen ${ }^{\odot}$ journal and benefit from:

- Convenient online submission

- Rigorous peer review

- Immediate publication on acceptance

Open access: articles freely available online

- High visibility within the field

- Retaining the copyright to your article

Submit your next manuscript at $\gg$ springeropen.com 